\title{
Coexistence of Formal and Informal Credit Markets in India -A Study of Entrepreneurial Choices for House-based Industries
}

\author{
Shrabani Mukherjee ${ }^{1, *}$ \\ ${ }^{1}$ Department of Economics, Birla Institute of Technology \& Science (BITS) Pilani University, \\ K.K.Birla Goa Campus, India \\ *Correspondence: Department of Economics, Birla Institute of Technology \& Science (BITS) \\ Pilani University, K.K.Birla Goa Campus, Near NH-17-B, Bye Pass Road, Zuari Nagar, \\ Goa-403726, India. E-mail: shrabani0808@gmail.com, shrabani@goa.bits-pilani.ac.in
}

Received: June 11, $2013 \quad$ Accepted: July 14, 2013 Published: July 25, 2013

doi:10.5296/rae.v5i3.3846 URL: http://dx.doi.org/10.5296/rae.v5i3.3846

\begin{abstract}
The exploitation of informal money lenders and huge debt burden on the rural labour force can't be ignored across India till now. The study assesses the underlying causes of existence of informal credit along with available subsidized formal credit in rural areas in India. It builds up a simple theoretical approach based on specific assumptions on entrepreneurial choice intended for sources of credit as investment to their house-based industries and thus evaluates the theoretical frame-work to a self-surveyed data set. It is empirically tested that the decision of the entrepreneurs is formed, basically, by the interaction between the cost of access to formal credit and the relative efficiency of formal and informal lending mechanisms. Institutional credit can't be effectively served until and unless a proper interlinked credit policy coupled with default management strategies, flexible terms and conditions along with wide branch networks sets up.
\end{abstract}

Keywords: formal and informal credit; entrepreneurial investment decision; cost of credit; logistic regression

JEL Classification: D13, R34, R38 


\section{Introduction}

The house-based industry (Note 1) is an integral part of India's rural prospect as it acts as a key to generating employment opportunities for the rural surplus labour force irrespective of gender, enhances entrepreneurial ability and provides economic benefits to the poor land less rural population and thus comprises deep end of rural poverty. Home based producers are some of the most invisible workers in the unorganized sector. This type of industry comprises a sizeable proportion of work force (Note 2). The economic contribution of these producers is often under estimated and they do not seem to have attracted much interest among academics and policy practitioners. In most of the policy analysis of rural development in India, they have either been completely unnoticed or incorporated as a component of small scale industries. Therefore, the specific problem that has been facing by these particular industries gets ignored. The basic crisis faced by these industries is huge capital scarcity though it uses less capital per unit of output. There is no second opinion that one of the vital factors influencing and supporting entrepreneurship is finance. In fact, together with a level playing field provided by appropriate and fair regulations and laws, and access to human capital, access to finance constitutes the pillars of entrepreneurship (UNDP, 2004). Despite having huge financial reforms and policies on priority sector lending, the needs of rural credit, as a whole, is not been adequately served through large, formal financial institutions till now. Due to emphasis on profitability, several bank branches in rural areas were closed which affected the credit services to the rural people and more so the poor. According to Handbook of Statistics of Indian Economy, during 1995-2009, the share of rural branches has declined at the rate of one per cent per annum. Specifically, the outstanding credit to Micro and Small Enterprises including manufacturing as well as service enterprises on March 2008 was only 9.3 percent of total Gross Bank Credit and it has increased only by 0.7 percentage point by the end of March 2009. The ground level credit flow by the Scheduled Commercial Banks has reduced from 27.36 percent in 2009-10 to 16.19 percent in 2010-11 as shown in Table 1.

Table 1: Agency-wise Ground Level Credit Flow (Rs. Crore Note 3)

\begin{tabular}{lllll}
\hline Agency & Cooperative Banks & $\begin{array}{l}\text { Regional } \\
\text { Rural banks }\end{array}$ & Commercial Banks & Total \\
\hline $2006-07$ & 42480 & 20435 & 166485 & 229400 \\
$2007-08$ & 48258 & 25312 & 181088 & 254658 \\
$2008-09$ & 45966 & 26765 & 228951 & $301908 * *$ \\
$2009-10$ & 63497 & 35217 & 285800 & 384514 \\
$2010-11$ & 70105 & 43968 & 332706 & 446779 \\
Growth Rate $(\%)$ & & & \\
$2006-10 *$ & 15.66 & 20.4 & 20.01 & 18.97 \\
$2009-10 *$ & 38.14 & 31.58 & 24.83 & 27.36 \\
$2010-11 *$ & 10.41 & 24.85 & 16.41 & 16.19 \\
\hline
\end{tabular}

\# Compound Annual Growth Rate *: Percentage change over previous year, **: Include Rs. 226 Crore by other Agencies.

Source: NABARD, Annual Report 2010-11. 
Apart from this, number of Self Help Groups (SHGs) (Note 4) financed by the Commercial Banks has decreased from 572 thousand to 312 thousand in 2007-08 over previous year. Although disbursements of credit by NABARD has increased Rs. 10535.29 crore in 2008-09 to Rs. 13485.87 crore in 2010-11, the credit to SHGs has reduced by 6 percent point of total disbursement over the same period. Given this background of rural credit flow by the formal institutions, informal lenders remain the dominant source of credit for poor households. The coexistence of formal and informal credit markets is now a widespread phenomenon in India. In informal credit markets, money is lent by private individuals, like professional moneylenders, traders, commission agents, landlords, friends, and relatives-generally out of their own equity. The cost of credit acts as an important demand side constraint in getting access to formal sector credit. This is the additional amount, over and above the amount borrowed, that the borrower has to pay. It includes interest, arrangement fees, transaction costs and other charges. In contrast, informal lenders manage more information about loan applicants and application procedures and thus, households are able to gain easier access to the informal sector at lower transaction costs. The study seeks to examine the reasons for the presence of a huge informal credit for landless rural entrepreneurs who are involved in house-based industries.

This study consists of six sections including the introduction and conclusion. Section 2 attempts to build up a simple theoretical model based on specific assumptions of individual's investment decision as an owner of house-based industry. Next section deals with the sample design, data and the methodology of empirical estimation. Section 4 describes the summary statistics of the variables used in the estimation and, therefore, section 5 discusses the results.

\section{Theoretical Framework}

The past studies, (Stiglitz and Weiss, 1981; Besley, 1995; Bell et al., 1997; Mohieldin and Wright, 2000; Anderson and Malchow-Moller, 2006; Boucher and Guirkinger, 2005; Li and Zhu, 2007; Chaudhuri and GhoshDastidar, 2011) basically, assumed that there is, typically, dual rural credit market in the developing countries. The credit rationing literature, generally, seeks to develop an economic justification for the allocation of credit by some means other than the price (interest rate). Most of this body of the literature followed from a pioneering work on credit rationing by Stiglitz and Weiss (1981). The study establishes that the interest rate, a lender charges, may itself affect the riskiness of the pool of loans by either sorting potential borrowers (the adverse selection effect) or affecting the actions of borrowers (the incentive effect). Through either of these effects, an interest rate that is set too high will inevitably cause the riskiness of the applicant's pool to increase. In the presence of subsidized formal credit, a market for informal credit exists either because the supply of formal credit is inadequate or because formal credit is not available at the beginning of the crop cycle (Gupta and Chaudhuri, 1996, Gupta and Chaudhuri, 1997 and Chaudhuri, 1999). It is, generally, assumed that formal credit supply would crowd out the informal credit market (Turvey and $\mathrm{R}$ Kong, 2010; Gine, 2011). The informal credit sector incessantly play dominant role in rural credit transactions and in many cases, the interest rate of informal sector has increased (rather 
than reduced) due to the interest ceiling and other regulations. Informal financial institutions play a complementary role to the formal financial system by servicing the lower end of the market and informal financing typically consists of small, unsecured, short term loans restricted to rural areas, agricultural contracts, households, individuals or small entrepreneurial ventures (Ayyagari, Kunt and Maksimovic, 2011; Barslund and Tarp, 2008). The existence of an informal credit market alongside a formal market where interest rates are substantially lower has long been recognized as a key feature of rural credit markets in developing countries and has received continuous attention in the field of development economics (Conning and Udry, 2005).

Not only is the persistent segmentation of credit markets into an expensive informal sector and a cheaper formal sector puzzling, it is also worrying on equity grounds. As the poor typically rely on expensive informal credit to finance their economic activities, they may systematically earn a lower return from their investment and thereby be on a slower wealth accumulation path than the rich who borrow in formal markets. Rural borrowers prefer to use informal sources of credit despite the fact that they charge much higher interest rates. This is perhaps because informal sources do not insist on regular repayment as banks or cooperative credit societies do (Banerjee and Duflo, 2010). Usually, it is possible to obtain loans for such purposes as marriage and attending to litigation only from informal sources and without collaterals (Pradhan, 2013). The informal sector is only the recipient of "spillover" demand from the formal sector (Diagne, Zeller and Sharma, 2000). But, poor, rural households prefer the informal credit despite having availability of formal credit because of the lower transaction costs and collateral risk (Boucher and Guirkinger, 2007). There is a systematic association between rate of interest and the value of collateral on the one hand, and marketability of collateral and interest rates on the other. In the context of household choice, it has shown that a risk rationed household is one that needs funds and has access to a credit contract but does not seek it because it is not willing to assume the downside risk implied by the available contract (Boucher et al., 2005). It has been empirically examined on the basis of surveyed panel data that the motives behind households' use of informal loans depends on relative worthiness of the contracts offered by the informal sector and by the formal sector in terms of effective cost and risk (Guirkinger, 2006). Further, in a survey of 13 developing countries brought out the fact that no more than 6 percent of the funds borrowed by the poor came from a formal source (Banerjee and Duflo, 2006). The vast majority of the rest comes from money lenders, friends or merchants. Informal credit markets are characterized by the following facts like lending rates can be very high relative to deposit rates within the same local area, lending rates can vary widely within the same credit markets, richer people borrow more and pay lower (often much lower) interest rates, people with few assets often do not borrow. These divergences in interest rates are not driven by the fact that a lot of these loans are not being repaid, rather the reason lies in the fact that defaults are relatively rare in this sector. The small business finance is characterized by the existence of formal and informal credit markets and looks at the operation of formal and informal credit market in terms of a model and considers the hierarchical structure of the formal lending sector and shows emergence of delay in loan disposal as a pooling equilibrium among all types of officials (Datta, 2009). The study presents the loan negotiation process in the formal sector as one of 
bargaining game. It is shown that the possibility of delay in the settlement of the loan negotiation can induce some of the borrowers to leave the formal credit market and go to the informal market. A study for a welfare evaluation of the credit liberalization finds the evidence of credit constraints as wealth, even controlling for talent, contributes significantly to business start-ups (Gine and Townsend, 2004; Paulson and Townsend, 2004). Therefore, it is established from previous studies that formal credit may be rationed in some periods and credit markets are segmented with local moneylenders, borrowers with no collateral may have to seek informal credit with high interest rates. However, the question remains, is informal credit productive than the formal credit? Very few literatures, theoretically and empirically, analyzed the factors that determine entrepreneurial choice and degree of access to formal credit in existing banking structure and found out the reason that drives the entrepreneurial choice function tilted towards informal credit. This particular study intends to analyze the choice of a borrower, as a firm owner, between the formal and informal source of credit for business investment and then it sheds light on the decisive factors that play a role for credit rationing as well as that make a fund (from formal and informal lenders) to be utilized for productive purposes in rural area.

This study assumes a perfect information framework where an owner of a home-based industry takes decisions about credit sources, which is the only input of production, based on the effective cost incurred in the process. The entrepreneur needs to raise funds to finance a positive investment project, and also needs to exert costly unobservable effort to make the investment profitable. In the informal sector, the cost of unobservable effort for the borrower can be relatively low. In contrast, the high transaction costs and other disadvantages (discussed in the previous section), here mentioned as a disutility related to loan application in the formal sector, may discourage households from taking formal loans. The entrepreneur's decision procedure has been developed by maximizing the profit function as follows:

Let us suppose the producer's production function is

$$
Q=f\left(L_{f}+L_{i}\right)
$$

Where $L_{f}$ and $L_{i}$ are the amount of loan borrowed from the formal sector and informal sector, respectively. For simplification it is assumed that both $L_{f}$ and $L_{i}$ behave as perfect substitutes.

Total cost to the producer would be:

$$
C=(1+r) L_{f}+(1+i) L_{i}
$$

Here, $r$ is the formal sector interest rate and ' $i$ ' is the informal sector interest rate. There exists some per unit disutility impact ' $\mathrm{e}$ ' for getting a loan from the formal sector. Then we have to incorporate ' $\mathrm{e}$ ' into the cost function. Now, the modified cost to the producer is 


$$
C=(1+r) L_{f}+(1+i) L_{i}+e \cdot L_{f}
$$

The profit function is

$$
\prod i=p \cdot f\left(L_{f}+L_{i}\right)-(1+r) L_{f}-(1+i) L_{i}-e . L_{f}
$$

We can get the first order conditions of profit maximization as:

$$
\begin{aligned}
& \frac{\partial}{\partial L_{f}} \prod i=p \cdot f^{\prime}\left(L_{f}+L_{i}\right)-(1+r)-e=0 \\
& p \cdot f^{\prime}\left(L_{f}+L_{i}\right)=1+r+e \\
& M C_{\text {formal }}=\frac{1+r+e}{p}
\end{aligned}
$$

Again

$$
\begin{aligned}
& \frac{\partial}{\partial L_{i}} \prod i=p \cdot f^{\prime}\left(L_{f}+L_{i}\right)-(1+i)=0 \\
& p \cdot f^{\prime}\left(L_{f}+L_{i}\right)=1+i
\end{aligned}
$$

$$
M C_{\text {inf ormal }}=\frac{1+i}{p}
$$

The producer takes a loan from the formal sector only if its marginal cost is less than the marginal cost of taking a loan from the informal sector.

$$
M C_{\text {formal }}>M C_{i \text { formal }}
$$

From Equations 4 and 5 we can get

$$
r+e<i
$$

Proposition 1: The producer never uses formal credit if the effective price of that exceeds the price of informal credit.

The costs of disadvantages in the formal sector may drive the effective cost of using informal loans below the effective cost of formal loans. This cost actually rations creditworthy borrowers in the formal sector. Therefore, they may take informal loans despite the higher rate of interest. In order to scrutinize the role of formal and informal credit markets in an 
entrepreneur's decision procedure separately, this study attempts to develop a simple model based on the framework sketched by Holmstrom and Tirole, 1997. For simplicity it assumes that all the agents in this model are risk neutral. Fixed size investment opportunity is denoted as I. Potential borrowers presumably face considerable costs and effort in obtaining external credit. If investors decide to apply effort, the rate of return of the project is $\ell>0$, and cash flow I $(1+\ell)$ is obtained; if the investor avoids to take any effort to take loan, the rate of return is $\ell$ only with probability $\mathrm{P}_{\mathrm{L}}<1$, and with complementary probability, it is 1 . There are two sectors in the rural credit market, viz., formal, and informal. In the formal credit market, the sources are banks, cooperatives, and formal monetary institutions. The sources of informal markets are shopkeepers, moneylenders, friend and relatives.

First, consider the formal credit market. The total disutility of effort for the investor is denoted as e and the formal rate of interest is denoted as $r$.

If the investor does not make any effort, the investment project gets a negative net present value $(\mathrm{NPV}), \mathrm{P}_{\mathrm{L}} \mathrm{I}(1+\ell)-\mathrm{I}(1+\mathrm{r})<0$. If the investor makes an effort, the project gets a positive NPV, I $(1+\ell)-\mathrm{e}-\mathrm{I}(1+\mathrm{r})>0$; as complementary probability is 1 .

Hence, e $<\mathrm{I}(\ell-\mathrm{r})=\prod_{\mathrm{F}}$,

where, $\prod_{F}$ is the financial margin earned on the investment when $\ell>r$.

If the repayment to the bank is denoted by $D$, the investor's expected profit is $I(1+\ell)-D-e$. If the investor avoids taking an effort, the expected payoff will be $\mathrm{P}_{\mathrm{L}}[\mathrm{I}(1+\ell)-\mathrm{D})$.

Now, effort can be incentive compatible if and only if, $\mathrm{I}(1+\ell)-\mathrm{e} /\left(1-\mathrm{P}_{\mathrm{L}}\right)>\mathrm{D}$

As, the rationality condition of the lender (expecting the investor to work) is, $\mathrm{D}=\mathrm{I}(1+\mathrm{r})$, the project can be financed by the formal sector if and only if,

$$
\begin{aligned}
& \mathrm{I}(1+\ell)-\mathrm{e} /\left(1-\mathrm{P}_{\mathrm{L}}\right)>\mathrm{I}(1+\mathrm{r}) . \\
& =>\mathrm{e}_{\mathrm{F}}=\prod_{\mathrm{F}}\left(1-\mathrm{P}_{\mathrm{L}}\right) \text { and } \mathrm{e}_{\mathrm{F}^{*}}=\prod_{\mathrm{F}}
\end{aligned}
$$

Proposition 2: The entrepreneur will make an effort to get a loan from the formal sector if the financial margin or net present value of the project will be positive.

Now, consider the informal credit market. The cost of funds in this case is denoted as $\Omega$, and the corresponding cost of effort is $\mathrm{e}_{@}=\mathrm{e}(1-\mathrm{k}), 0<\mathrm{k}<1$.

The project has a negative NPV when the investor shirks and consumes private benefits:

$\mathrm{P}_{\mathrm{L}} \mathrm{I}(1+\ell)<\mathrm{I}(1+\Omega)$, and can have a positive social net value if the investor exerts effort and the cost of the effort is low enough, i.e., $\mathrm{I}(1+\ell)-\mathrm{e}(1-\mathrm{k})=\mathrm{I}(1+\ell)-\mathrm{e}_{\varrho}>\mathrm{I}(1+\Omega)$,

or, $\mathrm{e}_{@}<\mathrm{I}(\ell-\Omega)=\prod_{\mathrm{I}}$

Where, $\prod_{I}$ shows the financial margin on investment when the project is funded by informal credit.

$=>\mathrm{e}_{\mathrm{I}}=\prod_{\mathrm{I}}\left(1-\mathrm{P}_{\mathrm{L}}\right)$ and $\mathrm{e}_{\mathrm{I}^{*}}=\prod_{\mathrm{I}}$ 
Proposition 3: The entrepreneur will make an effort to get a loan from the informal sector if the social net value of the project will be positive.

The theoretical explanation about the choice of entrepreneur seeks empirical evidence to plant a policy level prescription. This study attempts to evaluate the theoretical framework, discussed above, to a self-surveyed dataset. The survey carried out on Indian household industries based in two backward districts in West Bengal.

\section{Data and Methodology}

The data were collected from two backward districts (Note 5), viz., Murshidabad and Jalpaiguri of West Bengal in India in the year 2007-08. Although random, the sample lays out the characteristics as post-stratified in terms of occupation in both areas. In Murshidabad district, the total number of households interviewed was 146 across three police stations, viz. Sagardighi, Islampore and Berhampore. On the other hand, in Jalpaiguri district, 164 households were interviewed from Malbazar and Alipurduar sub-divisions (Note 6). The sample places are based on the concentration of population whose livelihoods are based on non-registered household industries. Here, the formal credit market includes credit delivered directly by formal institutions like banks or cooperatives or through bank programs like group lending that are governed by non-government organizations. Formal institutions generally do not ask for collateral if the loan is made by a group lending procedure. Here, all the respondent households are landless house-based industrial business owners. If there is a demand for credit, a household chooses to apply either to formal or an informal credit institution or both depending on their perceived relative probabilities of obtaining credit from each sector. These perceived probabilities are functions of the terms of credit demanded and borrowers' credibility and the supply of credit available to them. The assessment of households' decision of borrowing requires econometric analysis. Since the socio-economic and political conditions of Murshidabad and Jalpaiguri are different, the district dummy should be used to differentiate them. First, the study estimates the factors that affect an entrepreneur's decision to borrow from the formal sector following the multiple regression model specified as:

Model 1

$$
Y_{i}=\alpha_{01}+\alpha_{11} X_{1 i}+\alpha_{21} X_{2 i}+\alpha_{31} X_{3 i}+\ldots \ldots+\beta_{11} D_{1}+\beta_{21} D_{2}+\ldots \ldots
$$

Here, the dependent variable, $Y_{i}$, is the ratio of loan taken from the formal institution to total loan taken by the $\mathrm{i}^{\text {th }}$ entrepreneur. The independent variables, are denoted by different vectors, viz., $X_{i} s$ and $D_{i} s$. First vector represents households' characteristics, viz., gender of the respondent, age of the respondent, religion of the households, educational qualifications of the respondent, total number of earning members in the household, total number of dependents in the family, and annual average income of the household. Another important vector is the purpose of the formal sector loan (production, consumption, sudden event, previous loan payment or interest payment). Other categorical variables are distance to the 


\section{Macrothink}

Research in Applied Economics

ISSN 1948-5433

2013, Vol. 5, No. 3

formal lender, collateral or mortgages for the loan and other obstacles to getting a loan from formal sector, advantages to getting a loan from informal sector, annual interest rate in the formal sector, interest rate in the informal sector, and loan duration in the formal sector. The time taken to reach the lender proxies the distance to the lender and it have been used as the unobservable effort to obtain a loan from the formal or informal sector. There are a number of dummy variables to capture the effect of other political and sociological factors in dealing with the formal financial sector. Field experience supports the notion that the political affiliation of the household to the ruling party of the local government matters in obtaining membership in a group and eventually for getting a loan from a formal institution through group lending schemes.

Second objective is to find out the characteristics of making choice by the households separately for formal and informal credit markets. Specifically, it attempts to capture the likelihood that fund goes to productive purposes depends on different factors for two markets. This estimation uses binary logistic regressions as the dependent variable is a categorical in nature.

The basic form of the logistic function is,

$$
P=\frac{1}{1+e^{-Z}}
$$

Where ' $z$ ' is the predictor variable and 'e' is the base of the natural logarithm. Suppose that $z$ is a linear function of a set of predictor variables:

$$
z=b_{0}+b_{1} x_{1}+b_{2} x_{2}+\ldots \ldots \ldots \ldots \ldots \ldots \ldots . . . b_{k} x_{k}
$$

Where, $\mathrm{x} 1, \mathrm{x} 2 \ldots \ldots \ldots \ldots \mathrm{xk}$ are predictor variables.

Model 2

$$
\begin{aligned}
& \log \frac{P}{1-P}=b_{0}+b_{1} x_{1}+b_{2} x_{2}+\ldots \ldots \ldots \ldots \ldots . . . .+b_{k} x_{k} \\
& \operatorname{LogitP}_{f}=b_{0}+b_{1} x_{1}+b_{2} x_{2}+\ldots \ldots \ldots \ldots \ldots+b_{k} x_{k}
\end{aligned}
$$

Where, $\mathrm{P}_{\mathrm{f}}$ signifies the probability of getting a loan from the formal sector and $\mathrm{P}_{\mathrm{f}}=1,1-\mathrm{P}_{\mathrm{f}}=$ 0

Model 3

$$
\operatorname{logit} P_{i f}=c_{0}+c_{1} x_{1}+c_{2} x_{2}+\cdots+c_{k} x_{k}
$$

Where, $\mathrm{P}_{\text {if }}$ signifies the probability of getting a loan from the informal sector and $\mathrm{P}_{\text {if }}=1,1$ $\mathrm{P}_{\mathrm{if}}=0$ 


\section{Description of Variables}

The simple ordinary least squares (OLS) method used to examine the model specified as model 1. Model 2 makes a logistic framework about whether or not the loan borrowed from a formal institution goes toward working purposes. Basically, it determines the factors that responsible for the likelihood of the loan borrowed from the formal sector used in productive purposes. Similarly, model 3 finds out the reasons that drive the loan from the informal sector will be used for productive purposes. Table 2 gives the summary statistics of the dependent variables used in said three models. The mean, standard deviation (abbreviated as Std. in the table and discussion.

Table 2: Summery Statistics of the Dependent Variables

\begin{tabular}{|c|c|c|}
\hline Dependent Variables & $\begin{array}{l}\text { Number of } \\
\text { observations }\end{array}$ & Mean (Std.) \\
\hline Model 1: Formal Loan /Total Loan & 310 & $\begin{array}{l}0.412 \\
(0.342)\end{array}$ \\
\hline $\begin{array}{l}\text { Model 2: Probability that Formal Loan used for } \\
\text { Productive Purposes }\end{array}$ & 310 & $\begin{array}{l}0.487 \\
(0.501)\end{array}$ \\
\hline $\begin{array}{l}\text { Model 3: Probability that Informal Loan Used } \\
\text { for Productive Purposes }\end{array}$ & 310 & $\begin{array}{l}0.145 \\
(0.353)\end{array}$ \\
\hline
\end{tabular}

Table 3 presents the summary statistics of the exogenous variables based on general information of the household industry, like age of the entrepreneur, gender, educational qualifications, religion, number of earning members in the family, number of dependents, monthly average income of the household, ownership of a 'pukka'(Note 7) house, category of various household industries based on the nature of activities associated with it and the alternative occupation category.

Table 3: Summery Statistics of the Exogenous Variables

\begin{tabular}{|c|c|c|}
\hline Exogenous Variables & Description & Mean (Std) \\
\hline Sex & Dummy $($ Female $=1)$ & $0.652(0.477)$ \\
\hline Age of the Respondent & Continuous & \\
\hline $\begin{array}{l}\text { Years of Schooling of the } \\
\text { Respondent }\end{array}$ & Continuous & $3.629(3.077)$ \\
\hline Religion & Dummy $($ Hindu $=1$; Otherwise $=0)$ & $0.413(0.493)$ \\
\hline $\begin{array}{l}\text { Number of Earning } \\
\text { Members }\end{array}$ & Continuous & $2.567(0.840)$ \\
\hline $\begin{array}{l}\text { Number of Dependents in } \\
\text { the Household }\end{array}$ & Continuous & $2.458(1.057)$ \\
\hline $\begin{array}{l}\text { Monthly Average Income } \\
\text { of the Household }\end{array}$ & Continuous & $\begin{array}{l}2516.935 \\
(603.827)\end{array}$ \\
\hline Owner of 'Pakka' House & Dummy $($ Yes $=1$, otherwise $=0$ ) & $0.167(0.374)$ \\
\hline Alternative Occupation of & Household Labour $=0$ & $1.929(1.186)$ \\
\hline
\end{tabular}


The Household

Tea Garden Labour $=1$

Self-employed $=2$

Marginal farmer $=3$

Marginal labour $=4$

Bamboo Cane Crafts $=0$

Various House Based

Packet making $=1$

Industries

Piggery $=2$; Pottery $=3$; Poultry Firm $=4 ; 3.316$ (2.347)

Puffed Rice $=5 ;$ Sewing $=6 ;$ Vermi-pit $=7$

Weaving $=8$

Previous average monthly income is used as a proxy for entrepreneurial viability or ability of self-finance. Education of the borrower is measured by the years of schooling, since a higher level of education provides better knowledge and more information about the credit market. Age is used as a proxy for the potential for careful handling of the loans and repayment capability of the borrower. Since all the borrowers are landless rural workers, ownership of a 'pukka' house gives the idea of their current assets. Here, the respondents are the main owners of household industries. Since these household industries and alternative sources of income provide money throughout the year, the average monthly income has been calculated on the basis of their assessment.

Table 4: Summery Statistics of the Other Exogenous Variables

\begin{tabular}{|c|c|c|c|}
\hline Exogenous Variables & Description & $\begin{array}{l}\text { Mean } \\
(\mathrm{Std})\end{array}$ & $\begin{array}{l}\operatorname{Min} / \\
\operatorname{Max}\end{array}$ \\
\hline $\begin{array}{l}\text { Duration of loan } \\
\text { Or Total payback } \\
\text { period }\end{array}$ & $\begin{array}{l}\text { Category }=0, \text { if no loan taken } \\
=1, \text { if period is }<1 \text { month } ; \\
=2, \text { if } 1-6 \text { months } ; \\
=3 \text {, if } 7 \text { months }-1 \text { year; } \\
=4 \text {, if }>1 \text { year }-1.5 \text { year; } \\
=5, \text { if }>1.5 \text { year }-2 \text { years; } \\
=6, \text { if }>2 \text { years }-2.5 \text { years; } \\
=7, \text { if }>2.5 \text { years }-3 \text { years; } \\
=8, \text { if }>3 \text { years }\end{array}$ & $\begin{array}{l}1.635 \\
(1.53)\end{array}$ & $0 / 7$ \\
\hline $\begin{array}{l}\text { Collateral for formal } \\
\text { loan }\end{array}$ & $\begin{array}{l}\text { Categorical, } \\
\text { High }=3, \\
\text { Moderate }=2, \\
\text { Low }=1 \\
\text { Nil }=0\end{array}$ & $\begin{array}{l}0.413 \\
(0.74)\end{array}$ & $0 / 3$ \\
\hline $\begin{array}{l}\text { Political affiliation of } \\
\text { the Entrepreneur }\end{array}$ & $\begin{array}{l}\text { Dummy, affiliation to the ruling party in local } \\
\text { government }=1 \text {, } \\
\text { Otherwise }=0\end{array}$ & $\begin{array}{l}0.655 \\
(0.48)\end{array}$ & $0 / 1$ \\
\hline $\begin{array}{l}\text { Distance to the } \\
\text { formal lender }\end{array}$ & Continuous & $\begin{array}{l}37.49 \\
(37.68)\end{array}$ & $\begin{array}{l}0 / 150 \\
\mathrm{~km} .\end{array}$ \\
\hline $\begin{array}{l}\text { Interest rate in } \\
\text { formal sector }\end{array}$ & Continuous & $\begin{array}{l}8.018 \\
(5.84)\end{array}$ & $\begin{array}{l}0 / 21 \% \\
\text { per }\end{array}$ \\
\hline
\end{tabular}




\begin{tabular}{|c|c|c|c|}
\hline $\begin{array}{l}\text { Interest rate in } \\
\text { Informal sector }\end{array}$ & Continuous & $\begin{array}{l}25.583 \\
(14.49)\end{array}$ & $\begin{array}{l}0 / 42 \% \\
\text { per }\end{array}$ \\
\hline $\begin{array}{l}\text { Purpose of the } \\
\text { formal loan, majority } \\
\text { of the loan amount } \\
\text { goes for the } \\
\text { purposes. }\end{array}$ & $\begin{array}{l}\text { Categorical, Production }=1 \text {, Consumption }=2 \text {, } \\
\text { Event }=3 \text {, } \\
\text { Previous Loan repayment }=4\end{array}$ & $\begin{array}{l}0.913 \\
(0.88)\end{array}$ & $\begin{array}{l}\mathrm{nm} \\
0 / 4\end{array}$ \\
\hline $\begin{array}{l}\text { Purpose of the in } \\
\text { formal loan, majority } \\
\text { of the loan amount } \\
\text { goes for the purposes }\end{array}$ & $\begin{array}{l}\text { Categorical, Production }=1 \text {, Consumption }=2 \text {, } \\
\text { Event }=3 \text {, Previous Loan repayment }=4\end{array}$ & $\begin{array}{l}1.581 \\
(1.11)\end{array}$ & $0 / 4$ \\
\hline $\begin{array}{l}\text { SHG Member; } \\
\text { Dummy, } \\
\text { Yes }=1\end{array}$ & Associated with Self Help Group & $\begin{array}{l}0.426 \\
(0.49)\end{array}$ & $0 / 1$ \\
\hline $\begin{array}{l}\text { Obstacles to get } \\
\text { Formal Loans }\end{array}$ & Category & $\begin{array}{l}5.336 \\
(1.69)\end{array}$ & $0 / 7$ \\
\hline $\begin{array}{l}\text { Advantage to get } \\
\text { loan from informal } \\
\text { sector }\end{array}$ & Category & $\begin{array}{l}2.835 \\
(1.19)\end{array}$ & $0 / 5$ \\
\hline
\end{tabular}

Table 4 gives the summary statistics along with a description of the variables for other selected characteristics that may affect the entrepreneur's decision to borrow. These characteristics have been found to determine the decision to apply to either formal or informal lenders. Such characteristics include average annual interest rates in the formal as well as informal sectors, transaction costs that occur in the loan application in both sectors (measured by the time taken to cover the distance from the house to the lender) and other important qualitative dimensions of the study using categorical and dummy variables, like duration of the loan in terms of total payback period, the value of the collateral for a formal loan as felt by the borrowers, the purpose of borrowing for a formal loan and an informal loan, obstacles to getting a loan from the formal sector, the advantages of borrowing from the informal sector, political affiliation to the ruling party at the local Panchayat (Note 8), membership of a self-help group (SHG), and holder of a card that marks them as Below the Poverty Line (BPL).

\section{Empirical Findings}

This section brings out the underlying factors that affect credit rationing in formal credit market and the determinants of entrepreneur's choice between two sources of credit. This estimation also finds the incidence of formal sector rationing to be considerably higher than has been conventionally assumed. Here, the availability of credit or access to credit by borrowers has been explained in terms of the credit rationing behavior of lending institutions. 
But theoretically, this should depend on whether the individual has a demand for credit. In this analysis, 279 out of $310(90 \%)$ respondents who had borrowed can therefore be considered as having had a demand for credit. Hence, the size of the formal loan as a proportion of the total loan is considered as rationed credit. Model I estimates the most basic regression effect focusing on the amount of loan borrowed from the formal sector with respect to the total loan borrowed by the entrepreneur with five different specifications as shown in the different columns in Table 5.

Table 5: Results of Model1 with 5 Specifications

\begin{tabular}{|c|c|c|c|c|c|}
\hline \multirow[t]{2}{*}{$\begin{array}{ll}\text { Formal Loan } & \text { Lotal Loan }\end{array}$} & $\begin{array}{l}\text { Coefficient } \\
\text { (Std. Err.) }\end{array}$ & $\begin{array}{l}\text { Coefficient } \\
\text { (Std. Err.) }\end{array}$ & $\begin{array}{l}\text { Coefficient } \\
\text { (Std. Err.) }\end{array}$ & $\begin{array}{l}\text { Coefficient } \\
\text { (Std. Err.) }\end{array}$ & $\begin{array}{l}\text { Coefficient } \\
\text { (Std. Err.) }\end{array}$ \\
\hline & I & II & III & IV & $\mathrm{V}$ \\
\hline \multirow[t]{2}{*}{ Sex } & 0.0562 & & & & 0.00085 \\
\hline & $(0.043)$ & & & & $(0.0009)$ \\
\hline \multirow[t]{2}{*}{ Age } & -0.0016 & & & & -0.002 \\
\hline & $(0.002)$ & & & & $(0.0192)$ \\
\hline \multirow{2}{*}{$\begin{array}{l}\text { Years of } \\
\text { Schooling }\end{array}$} & -0.0035 & & & & .0012 \\
\hline & $(0.0069)$ & & & & $(0.00839)$ \\
\hline \multirow{2}{*}{$\begin{array}{l}\text { Number of } \\
\text { Earning Members }\end{array}$} & $0.0383^{*}$ & & & & -.008 \\
\hline & $(0.023)$ & & & & $(0.011)$ \\
\hline Number of & 0.0006 & & & & -.00103 \\
\hline $\begin{array}{l}\text { Dependents in the } \\
\text { Household }\end{array}$ & $(0.019)$ & & & & $(0.003)$ \\
\hline \multirow{2}{*}{$\begin{array}{l}\text { Monthly Average } \\
\text { Family Income }\end{array}$} & 0.00002 & $0.0000243 *$ & $0.000026^{*}$ & & 0.000019 \\
\hline & $(0.00003)$ & $(0.00001)$ & $(0.00001)$ & & $(0.000015)$ \\
\hline \multirow{2}{*}{$\begin{array}{l}\text { Religion, Hindu }= \\
1 ; \text { Otherwise }=0\end{array}$} & -0.0582 & & & & -.01239 \\
\hline & $(0.047)$ & & & & $(0.024)$ \\
\hline \multirow{2}{*}{$\begin{array}{l}\text { 'Pakka' House } \\
\text { Dummy }\end{array}$} & $0.0990 *$ & & & & 0.007 \\
\hline & $(0.056)$ & & & & $(0.025$ \\
\hline \multirow{2}{*}{$\begin{array}{l}\text { Alternative } \\
\text { Occupation } \\
\text { Category }\end{array}$} & -0.0202 & & & & .012 \\
\hline & $(0.0198)$ & & & & $(0.008)$ \\
\hline \multirow{2}{*}{$\begin{array}{l}\text { Specific } \\
\text { Industrial } \\
\text { Category }\end{array}$} & $0.0201 * *$ & & & & -.0031 \\
\hline & $(0.009)$ & & & & $(0.004)$ \\
\hline \multirow{2}{*}{$\begin{array}{l}\text { Interest rate/ } \\
\text { formal }\end{array}$} & & $-0.00618 * * *$ & $-.0068766^{* * *}$ & $-0.0071 * * *$ & $-.0066^{* * *}$ \\
\hline & & $(0.00084)$ & $(0.00078)$ & $(0.001)$ & $(0.00067)$ \\
\hline
\end{tabular}




\begin{tabular}{|c|c|c|c|c|c|}
\hline \multirow[t]{2}{*}{$\begin{array}{l}\text { Formal Loan } \\
\text { /Total Loan }\end{array}$} & $\begin{array}{l}\text { Coefficient } \\
\text { (Std. Err.) }\end{array}$ & $\begin{array}{l}\text { Coefficient } \\
\text { (Std. Err.) }\end{array}$ & $\begin{array}{l}\text { Coefficient } \\
\text { (Std. Err.) }\end{array}$ & $\begin{array}{l}\text { Coefficient } \\
\text { (Std. Err.) }\end{array}$ & $\begin{array}{l}\text { Coefficient } \\
\text { (Std. Err.) }\end{array}$ \\
\hline & I & II & III & IV & $\mathrm{V}$ \\
\hline \multirow{2}{*}{$\begin{array}{l}\text { Interest rate/ } \\
\text { Informal }\end{array}$} & & $0.04583 * * *$ & $0.02052 * * *$ & $0.02061 * * *$ & $.02134 * * *$ \\
\hline & & $(0.00225)$ & $(0.0042)$ & $(0.0044)$ & $(0.004)$ \\
\hline \multicolumn{2}{|l|}{ Duration } & & & -0.0029366 & -.0038 \\
\hline \multicolumn{2}{|l|}{ Category } & & & $(0.005)$ & $(0.0055)$ \\
\hline \multirow[t]{2}{*}{ Poverty (BPL) } & & & 0.01793 & 0.01311 & .01445 \\
\hline & & & $(0.01647)$ & $(0.017)$ & $(0.017)$ \\
\hline \multirow[t]{2}{*}{ District } & & $0.04020 *$ & & $0.03601 *$ & .0182 \\
\hline & & (0.02009) & & $(0.02)$ & $(0.025)$ \\
\hline \multicolumn{2}{|l|}{ Political } & & $0.36373 * * *$ & $0.3301 * * *$ & $.323227 * * *$ \\
\hline \multicolumn{2}{|l|}{ Affiliation } & & $(0.05239)$ & $(0.055)$ & $(0.056)$ \\
\hline \multicolumn{2}{|l|}{ Collateral } & & & -0.0017 & \\
\hline \multicolumn{2}{|l|}{ Formal } & & & $(0.013)$ & \\
\hline & 0.01461 & & 0.0112 & .01036 \\
\hline \multicolumn{6}{|l|}{ Loan } \\
\hline \multirow{2}{*}{$\begin{array}{l}\text { Purpose of } \\
\text { Informal Loan }\end{array}$} & & & & $0.0215 * *$ & \\
\hline & & & & $(0.011)$ & \\
\hline \multirow{2}{*}{$\begin{array}{l}\text { Obstacles for } \\
\text { Formal Loan }\end{array}$} & & & & -0.0111 & $-.01115^{*}$ \\
\hline & & & & $(0.007)$ & $(0.0075)$ \\
\hline \multicolumn{2}{|l|}{$\begin{array}{l}\text { Advantages in } \\
\text { Informal Sector }\end{array}$} & & & $-0.0150 *$ & $-.01427 * *$ \\
\hline Informal Sector & & & & $(0.008)$ & $(0.008)$ \\
\hline \multirow{2}{*}{ SHG Dummy } & & & & -0.01159 & 0.0024 \\
\hline & & & & $(0.0198)$ & $(0.02)$ \\
\hline \multirow{2}{*}{$\begin{array}{l}\text { Distance to } \\
\text { Formal Lender }\end{array}$} & & $-0.00101 * * *$ & -.00058 & $0.0009 * *$ & \\
\hline & & $(0.00077)$ & $(0.0007)$ & $(0.0002)$ & \\
\hline \multirow[t]{2}{*}{ _cons } & $0.3953 * *$ & $0.0784 * *$ & $0.09313^{*}$ & $0.2475^{* * *}$ & $.18095 *$ \\
\hline & $(0.143)$ & $(0.04345)$ & $(0.04086)$ & $(0.059)$ & $(0.0856)$ \\
\hline
\end{tabular}

Note: $* * *$ means significant at $1 \%$; ** means significant at $5 \%$ and $*$ means significant at $10 \%$ level.

The specifications or different set of exogenous variables have been selected on the basis of the values of $\mathrm{R}^{2}$ and results of multi-collinearity by the trial-and-error method. The 
specification I indicates that the variables, like 'number of earning members in a family', 'household industrial category' and 'owner of a pukka house' are significant with positive coefficients. This means that these variables have a positive impact on borrowing of formal credit or are eventually negatively involved in credit rationing. Among all household industrial categories, those that are involved in sewing, weaving, or vermi-pit get more loans from the formal sector than the informal sector, perhaps because these house-based industries have a proper project design that eventually pulls formal credit toward them. Column II provides an interesting assessment about the interest rates in the formal credit market as well as the informal credit sector. The interest rate in the formal sector is significant at the $1 \%$ level with a negative coefficient. It is obvious that the higher the value of the interest rate, the lower is the demand for credit from the formal sector.

Further, the coefficient for informal interest rate is positive and significant. This implies an interesting implicit horizontal linkage between the informal interest rate and formal sector credit demand. The interest rates in both the formal and informal sectors directly and/ or indirectly determine the demand for credit in the formal sector. On the other hand, the distance to the formal lender and that of the informal sector which proxy the transaction costs associated with the loan application from their respective sources are significant at the $1 \%$ and $10 \%$ levels, respectively, with negative and positive signs for the coefficients. Therefore, it can be said that these three variables are imperative determinants of credit rationing in the formal sector. It should be expressed that the insignificant results of household characteristics, like gender, age, educational qualifications, religion, and number of dependents suggest that, once other factors are controlled for, these factors do not have any role in credit rationing in the formal sector. Moreover, the variable 'district dummy' is included in order to get the region bias in this analysis. It shows significant impact. Since Murshidabad district is represented by 1 and Jalpaiguri is symbolized by 0 in the dataset, the people in Murshidabad are keener on formal sector credit demand than people in Jalpaiguri. Column III adds the political affiliation factor as a major driver of credit availability in the formal sector. Column IV includes membership in a group as a significant determinant in this case. Column V includes advantages in the informal sector and obstacles in the formal sector as a significant factor in demand for a loan in the formal sector. Further, this study argues that while loan demand is unobservable, it can be inferred under certain behavioral restrictions by aggregating individual loans received from various types of lenders. It therefore becomes important to take the determinants of interest rate differentiation between the two sectors. Another econometric framework is developed to estimate factors responsible for huge variation in interest rates between the two sectors as well as between the borrowers. Since in the formal sector interest rates are more or less within an equal range, this estimation, eventually, gives the results of variation in interest rates in the informal sector.

Models 2 and model 3 estimate the determinants of maximum likelihood of the major proportion of the loan going to the productive purposes for the formal and informal sectors respectively using binomial logistic regressions are shown in Table 6. 
Table 6: Binomial Logistic Regressions

\begin{tabular}{|c|c|c|c|c|}
\hline Variables & Model 2 & & Model 3 & \\
\hline Sex & $\begin{array}{l}\text { Coefficient } \\
\text { (Std. Err.) } \\
-0.1559 \\
(0.409)\end{array}$ & $\begin{array}{l}\text { Marginal } \\
\text { Effects } \\
*_{-0.0165} \\
(0.068)\end{array}$ & $\begin{array}{l}\text { Coefficient } \quad \text { Std. } \\
\text { Err.) } \\
0.345^{*} \\
(0.461)\end{array}$ & $\begin{array}{l}\text { Marginal } \\
\text { Effects } \\
* 0.0217 \\
(0.023)\end{array}$ \\
\hline Age & $\begin{array}{l}-0.0167 \\
(0.018)\end{array}$ & $\begin{array}{l}-0.004 \\
(0.003)\end{array}$ & $\begin{array}{l}-0.001 \\
(0.023)\end{array}$ & $\begin{array}{l}-0.0003 \\
(0.001)\end{array}$ \\
\hline Years of Schooling & $\begin{array}{l}0.0549 \\
(0.057)\end{array}$ & $\begin{array}{l}0.008 \\
(0.102)\end{array}$ & $\begin{array}{l}0.066 \\
(0.061)\end{array}$ & $\begin{array}{l}0.004 \\
(0.003)\end{array}$ \\
\hline Dependency Ratio & $\begin{array}{l}0.363 \\
(0.356)\end{array}$ & $\begin{array}{l}0.0639 \\
(0.063)\end{array}$ & $\begin{array}{l}-0.026 \\
(0.395)\end{array}$ & $\begin{array}{l}-0.0056 \\
(0.021)\end{array}$ \\
\hline Income class & $\begin{array}{l}3.33 * * \\
(1.461)\end{array}$ & $\begin{array}{l}0.532 \\
(0.128)\end{array}$ & $\begin{array}{l}0.182 * * \\
(2.170)\end{array}$ & $\begin{array}{l}0.008 \\
(0.115)\end{array}$ \\
\hline Formal Loan /Total Loan & $\begin{array}{l}5.885 * * * \\
(1.405)\end{array}$ & $\begin{array}{l}0.608 \\
(0.259)\end{array}$ & $\begin{array}{l}-8.692 * * * \\
(2.230)\end{array}$ & $\begin{array}{l}-0.48 \\
(0.118)\end{array}$ \\
\hline Loan Duration & $\begin{array}{l}-0.128 \\
(0.206)\end{array}$ & $\begin{array}{l}0.037 \\
(0.021)\end{array}$ & $\begin{array}{l}0.242 * * \\
(0.268)\end{array}$ & $\begin{array}{l}0.0047 \\
(.0068)\end{array}$ \\
\hline District Dummy & $\begin{array}{l}-0.104 * \\
(0.394)\end{array}$ & $\begin{array}{l}*_{-} 0.0432 \\
(0.086)\end{array}$ & $\begin{array}{l}-0.583^{*} \\
(0.469)\end{array}$ & $\begin{array}{l}*_{-} 0.007 \\
(0.025)\end{array}$ \\
\hline BPL; Yes=1. & $\begin{array}{l}0.185 \\
(0.352)\end{array}$ & $\begin{array}{l}* 0.022 \\
(0.063)\end{array}$ & $\begin{array}{l}-0.057 \\
(0.375)\end{array}$ & $\begin{array}{l}* 0.0046 \\
(0.02)\end{array}$ \\
\hline $\begin{array}{l}\text { Interest rate/formal } \\
\text { sector }\end{array}$ & $\begin{array}{l}-0.151 * * \\
(0.071)\end{array}$ & $\begin{array}{l}-0.001 \\
(0.018)\end{array}$ & $\begin{array}{l}-0.116^{* *} \\
(0.0108)\end{array}$ & $\begin{array}{l}-0.005 \\
(0.006)\end{array}$ \\
\hline $\begin{array}{l}\text { Interest rate in Informal } \\
\text { sector }\end{array}$ & $\begin{array}{l}0.078 * * * \\
(0.025)\end{array}$ & $\begin{array}{l}0.0084 \\
(0.0041)\end{array}$ & $\begin{array}{l}0.038 * * \\
(0.030)\end{array}$ & $\begin{array}{l}0.0025 \\
(.001)\end{array}$ \\
\hline $\begin{array}{l}\text { Distance of the formal } \\
\text { Lender }\end{array}$ & $\begin{array}{l}-5.623 * * * \\
(1.52)\end{array}$ & $\begin{array}{l}0.603 \\
(0.248)\end{array}$ & $\begin{array}{l}0.394 * * \\
(0.101)\end{array}$ & $\begin{array}{l}0.031 \\
(0.121)\end{array}$ \\
\hline $\begin{array}{l}\text { Advantage of the } \\
\text { informal }\end{array}$ & $\begin{array}{l}-0.1054 \\
(0.171)\end{array}$ & $\begin{array}{l}-0.0137 \\
(0.031)\end{array}$ & $\begin{array}{l}3.394 * * * \\
(1.324)\end{array}$ & $\begin{array}{l}0.82 \\
(0.172)\end{array}$ \\
\hline
\end{tabular}


income class, the higher is the probability that the formal loan will be used as working capital. The interesting fact is that this income class follows the same relationship with considerable effect for the informal sector too. This shows that people in a higher income class prefer to invest in business from the loan irrespective of its source. Another result shows that if the entrepreneur gets more money from formal lenders he/she prefers to use more for business purposes. Both transaction cost and interest rates matter in these cases. The interest rate in the formal sector poses a negative relation for the formal sector and also lies in a negative relation for the informal sector. This leads to the conclusion that if the formal sector interest rate increases, the money used for business purposes from the informal sector will also decrease. This may be because whenever the interest rate in the formal sector increases, informal lenders deliberately raise their interest rates. Eventually, it follows the same dimension. Another result reveals that membership in a self-help group does not have a significant result in the case of formal credit but it has a significant negative impact for informal credit. The reason (gathered from field experience) is that if the entrepreneur becomes a member of a group (availing of a group lending program), the informal lender avoids giving him/her a loan during that period. However, the empirical results, in broader structure, support the theoretical propositions laid out in Section 2. The first proposition claims that interest rate alone is not responsible for credit demand from the concerned source. The empirical findings also show that although the interest rate is much lower in the formal sector, the producer prefers to use the informal sector because of the lower effective rate of interest (actual interest rate and transaction cost). The second proposition claims that the effort of taking a loan from the formal sector depends on the profitability of the project or business using that loan. Since the study does not have data on the profit of the business in 2008-09, it was compelled to use income level. As Model 2 states that the likelihood of the formal loan used as working capital depends on income class, the second proposition is satisfied. Similarly, the third proposition claimed that the effort of taking a loan from informal sector depends on whether the social net present value of the project is positive. The distribution of the data supports the probability that informal loan used as working capital in the business depends on the advantages associated with the informal sector. Therefore, the third proposition is also satisfied from the empirical analysis.

\section{Conclusion}

The empirical findings of this paper support the notion that the incidence of formal sector rationing is considerably high. In this context, this study addressed two basic quarries-first, what are the factors that affect entrepreneurs' choice about sources of borrowing the capital for business and second, what determines that the borrowed capital go to productive purposes? Although entrepreneur's investment decision mainly drives by interest rates, distance to the formal lender, political affiliation of the household, and some obstacles to get loan from the formal sector are the significant factors that impinge on borrowing from formal sector. The potential borrowers need credit. But, the lending terms and conditions prevent them from seeking credit from the formal institutions. On the other hand, informal credit is confined to specific activities like, consumption, sudden event and repayment of loan for the 
lower income class: thus limiting its use. Some potential borrowers can't get access to the formal sources because of high transaction cost and also can't fully depend on informal sector for high interest rate and other disadvantages. Therefore, in order to capture all potential borrowers there is a need to improve the access to institutional credit across income levels. A wide branch network of development banks with more lenient lending terms and conditions in favor of household enterprises is truly necessary. The recent emergence of micro credit programs (or self help groups) should act as panacea but they have their own obstacles like decimal profitability, inefficient monitoring, imperfect financial auditing and local political influence and obligations. Given the relatively more financial resources of the formal institutions compared with informal credit sources, government should stand as sole institution rather than behaving like financial intermediaries. This can be achieved firstly, through the expansion of branch networks with unit level monitoring through trained bank officials. Probably, establishment of credit insurance schemes may protect the financial institutions against default risks, which result in credit rationing. On the other hand, if a credit subsidy policy is undertaken through an increase in supply of institutional credit it is likely to increase the competitiveness in the informal credit market and lower the informal interest rate too.

\section{Acknowledgement}

Thanks to Krishnendu Ghosh Dastidar, Jawaharlal Nehru University and Debdulal Thakur, BITS-Pilani University for useful comments and suggestions during the study.

\section{References}

Aleem, I. (1990). Imperfect Information, Screening, and the Costs of Informal Lending: A Study of a Rural Credit Market in Pakistan. World Bank Economic Review, 4(3), 329-349. http://dx.doi.org/10.1093/wber/4.3.329

Anderson \& Malchow-Moller. (2006). Strategic Interaction in Undeveloped Credit Markets.
Journal
of Development
Economics,
$80(2)$,
275-298.

http://dx.doi.org/10.1016/j.jdeveco.2005.03.001

Ayyagari. M, AsliDemirgüç-Kunt, \& Vojislav Maksimovic. (2011). Formal versus Informal Finance: Evidence from China. Review of Financial Studies, 23(8), 3048-3097

Banerjee, A., \& Duflo, E. (2006). The Economic Lives of the Poor. CEPR Discussion Papers 5968, C.E.P.R. Discussion Papers.

Banerjee. A., \& Duflo E. (2010). Giving Credit where It Was Due. The Journal of Economic Perspectives, 24(3), 61-79. http://dx.doi.org/10.1257/jep.24.3.61

Barslund. M., \& F. Tarp. (2008). Formal and Informal Rural Credit in Four Provinces of Vietnam. The Journal of Development Studies, 44(4), 485-503. http://dx.doi.org/10.1080/00220380801980798 
Bell, C., Srinivasin, T.N., \& Udry, C. (1997). Rationing, Spillover, and Interlinking in Credit Markets: the Case of Rural Punjab. Oxford Economic Papers. Oxford University Press, 4(49), 557-585. http://dx.doi.org/10.1093/oxfordjournals.oep.a028625

Besley. (1995). Nonmarket Institutions for Credit and Risk Sharing in Low-Income Countries. The Journal of Economic Perspectives, 9(3), 115-127. http://dx.doi.org/10.1257/jep.9.3.115

Boucher, S.R., \& C. Guirkinger, (2005). Risk, Wealth, and Sectoral Choice in Rural Credit Markets. American Journal of Agricultural Economics, 89(4), 991-1004. http://dx.doi.org/10.1111/j.1467-8276.2007.01009.x

Boucher, S.R., Carter, M., \& Guirkinger, C. (2007). Credit Constraints and Productivity in Peruvian Agriculture. Working Paper No. 07-005. Department of Agricultural and Resource Economics, University of California - Davis.

Chaudhuri, S., \& K. G. Dastidar. (2011). Vertical Linkage between Formal and Informal Credit Markets: Corruption and Credit Subsidy policy. Munich Personal RePEc Archive. MPRA Paper No. 35563.

Chaudhuri, S., \& M.R. Gupta. (1996). Delayed Formal Credit, Bribing and the Informal Credit Market in Agriculture: A Theoretical Analysis. Journal of Development Economics, 51, 433-449. http://dx.doi.org/10.1016/S0304-3878(96)00407-5

Chaudhuri, S. (1999). Inadequate Formal Credit and the Informal Credit Market in Agriculture: A Theoretical Analysis. Journal of Quantitative Economics, 14(2), 123-134.

Conning, J., \& Udry, C. (2005). Rural Financial Markets in Developing Countries. Prepared for the Handbook of Agricultural Economics, vol. 3, edited by E. Pingali and T. P.Shultz.

Datta, D. (2009). Small Business Finance - Implication of Delay in Loan Sanctions by Formal Sector. Retrieved fromhttp://ssrn.com/abstract=1350206

Diagne,A., Zeller, M., \& Sharma M. (2000). Empirical Measurements of Households' Access to Credit and Credit Constraints in Developing Countries: Methodological Issues and Evidence. FCND Discussion Paper No. 90. IFPRI.

Gin'e. X. (2011). Access to Capital in Rural Thailand: An Estimated Model of Formal vs. Informal Credit. Journal of Development Economics, 96, 16-29. http://dx.doi.org/10.1016/j.jdeveco.2010.07.001

Gine \& Townsend. (2004). Evaluation of Financial Liberalization: A General Equilibrium Model with Constrained Occupation Choice. Journal of Development Economics, 74, 269- 307. http://dx.doi.org/10.1016/j.jdeveco.2003.03.005

Guirkinger, C. (2006). Understanding the Coexistence of Formal and Informal Credit Markets in Piura, Peru. Center for Research in Economic Development, University of Namur, Belgium.

Gupta, M. R., \& S, Chaudhuri. (1997). Formal Credit, Corruption and the Informal Credit 
Market in Agriculture A Theoretical Analysis. Economica, 64, 331-43. http://dx.doi.org/10.1111/1468-0335.00081

Handbook of Statistics of Indian Economy, RBI, various years

HolmstromBengt, Jean Tirole. (1997). Financial Intermediation, Loanable Funds, and the Real Sector. The Quarterly Journal of Economics, 112(3), 663-691. http://dx.doi.org/10.1162/003355397555316

Li. R., \& Zhu X. (2007). Econometric Analysis of Credit Constraints of Rural Households and Welfare Loss. Economic Research, 2, 146-155

Mohieldin \& Wright. (2000). Formal and Informal Credit Market in Egypt. Economic Development and Cultural Change, 48(3), 657-670. http://dx.doi.org/10.1086/452614

National Bank for Agriculture and Rural Development, Annual Report, 2010-11.

Paulson \& Townsend. (2004). Entrepreneurship and financial constraints in Thailand. Journal of Corporate Finance, 10, 229-262. http://dx.doi.org/10.1016/S0929-1199(03)00056-7

Pradhan. N. C (2013). Persistence of Informal Credit in Rural India: Evidence from 'All-India Debt and Investment Survey' and Beyond. RBI Working Paper Series, 5.

Stiglitz, J. E., \& A. Weiss. (1981). Credit Rationing in Markets with Imperfect Information. American Economic Review, 71, 393-410.

Turvey. C. G., \& R. Kong. (2010). Informal Lending Amongst Friends and Relatives: Can Microcredit Compete in Rural China? China Economic Review, 21(4), 544-556. http://dx.doi.org/10.1016/j.chieco.2010.05.001

\section{Notes}

Note 1. According to Census 2001, India, a household industry is known as an industry carried out by the head of the household or by the members of households at home or within the village in rural areas and only within the confines of house where the household lives at urban areas.

Note 2. It can be mentioned, as per the Economic Survey (2006/07), that the micro and small enterprises constitute an important segment of the Indian economy, contributing about 39 percent of the countries manufacturing output and 34 percent of its exports in 2004/05. It provided employment to around 29.5 million people in the rural and urban areas of the country.

Note 3.1 Crore $=10$ Million

Note 4. A self-help group ( $\mathrm{SHG}$ ) is defined as a rural financial intermediary usually composed of 10-20 local members. It typically comprises a group of micro entrepreneurs, having similar social and economic backgrounds. All members voluntarily come together to save regular small sums of money, mutually agreeing to contribute to a common fund and to 
meet their emergency needs on the basis of mutual help.

Note 5. A 'district' is an administrative division of an Indian state or territory. There are 671 districts in India now. There were a total of 640 districts in India in 2011.

Note 6. The Administrative divisions of India are Indian sub-national administrative units; they compose a nested hierarchy of country subdivisions. The smaller subdivisions (villages and blocks) exist only in rural areas. In urban areas Urban Local Bodies exist instead of these rural subdivisions.

Note 7. Pucca housing (or pukka) refers to dwellings that are designed to be solid and permanent. The term is applied to housing built of substantial material such as stone, brick, cement, concrete, or timber.

Note 8. 'Panchayat' is a South Asian political system mainly in India, Pakistan, Bangladesh and Nepal. It is the oldest system of local government in the Indian subcontinent.

\section{Copyright Disclaimer}

Copyright reserved by the author(s).

This article is an open-access article distributed under the terms and conditions of the Creative Commons Attribution license (http://creativecommons.org/licenses/by/3.0/). 